\title{
Duodenal ulceration: review of 110 cases
}

\author{
M S MURPHY, E J EASTHAM, M JIMENEZ, R NELSON, AND R H JACKSON \\ Department of Child Health, Royal Victoria Infirmary, Newcastle upon Tyne
}

\begin{abstract}
SUMmaRY This paper describes 110 cases of childhood duodenal ulcer, which were diagnosed over 26 years: 63 were diagnosed by barium meal examination; 47 by upper gastrointestinal endoscopy. The mean age at diagnosis was 11.2 years, with symptoms reported in $46 \%$ before 10 years and in $15 \%$ before 6 years of age. There was often a considerable delay in diagnosis, particularly in the younger age group. Nocturnal pain $(61 \%)$ and a close family history of duodenal ulcer disease $(62 \%)$ were the most valuable pointers to the diagnosis. Fifteen children had required surgery for persistent symptoms. Thirty four had received treatment with an $\mathrm{H}_{2}$ receptor antagonist, and all but four had had a satisfactory initial response. Seventy per cent relapsed within six months of discontinuing treatment, and long term maintenance treatment may therefore be necessary.
\end{abstract}

Recurrent abdominal pain is a common disorder in childhood, and it is well known that an organic disorder can be identified in only a minority of cases. ${ }^{1}$ None the less, a small but significant number of these children have a peptic ulcer, usually in the duodenum.

The introduction of fibreoptic endoscopy to paediatric practice has permitted direct and accurate diagnosis of peptic ulcer. ${ }^{23}$ The development of the $\mathrm{H}_{2}$ receptor antagonists has facilitated medical management and so increased the importance of early diagnosis.

In the past 26 years a large number of cases of duodenal ulceration in childhood have been seen in the Newcastle area. In this report we review the experience gained in the diagnosis and management of these children. We suspect that the diagnosis may often be delayed, if not completely overlooked, especially in young children.

\section{Patients}

The case histories of 110 children with primary duodenal ulceration were reviewed. All had been seen in the 26 years between 1960 and 1985 . They had attended either the Royal Victoria Infirmary, Newcastle upon Tyne, or the Queen Elizabeth Hospital, Gateshead, and each patient had been assessed personally by one of the authors.

Between 1960 and 197263 cases were diagnosed by barium meal examination. The diagnosis was accepted only if an ulcer crater could be shown, or if there was pronounced deformity of the duodenal cap and strong clinical evidence of active ulcer disease, such as haematemesis or melaena. Between 1973 and 1985 a further 47 cases were diagnosed by upper gastrointestinal endoscopy.

\section{Results}

Sex incidence. Of the 110 children, 87 were male and 23 female, a ratio of $3 \cdot 8: 1$. This predominance of males agrees with that reported in other series. ${ }^{4-6}$

Socioeconomic groups. Cases were found in all socioeconomic groups, and when compared with the local population distribution, no excessive preponderance within any one group could be identified.

Family history. In $62 \%$ at least one first or second degree relative had had confirmed duodenal ulcer disease. The diagnosis had been established in all by radiology, endoscopy, or at surgery. The family incidence was sometimes highly impressive-for example, in the case of one boy two male siblings and the father were affected.

Age at onset of symptoms and at diagnosis. The mean age at diagnosis was only 11.2 years, and the children ranged from 4 to 15 years. Interestingly, symptoms were reported to have been present in $46 \%$ before the age of 10 and in $15 \%$ before 6 years of age. The mean interval from the reported onset of 
symptoms to the time of diagnosis was 1.8 years. When symptoms began in early childhood the delay in diagnosis was likely to be considerably longer (Table 1): thus in those who were symptomatic by 6 years the mean interval to diagnosis was 4.8 years.

\section{Clinical features (Table 2)}

Abdominal pain occurred in $90 \%$ of cases and was a main presenting feature in $88 \%$. In $48 \%$, however, it was not suggestive of ulcer dyspepsia. The pain was located in the epigastrium in only $51 \%$ of cases, while in $36 \%$ it was maximal in the central abdomen. A temporal relation to meal times was described in only $52 \%$ of the cases. Periodicity was a common feature, being present in $71 \%$. Nocturnal pain was present in 67 patients $(61 \%)$. If those who presented with gastrointestinal bleeding are excluded, whom, it is presumed, would have already been investigated, $80 \%$ of the remainder had nocturnal pain.

Change in appetite was not a notable feature. Episodes of vomiting had occurred in $39 \%$, but on each occasion this was accompanied by pain, and all had had previous episodes of pain.

Epigastric tenderness was not usually a striking feature. Some degree of tenderness was noted in $54 \%$, but its absence may relate to the state of activity of the disease at the time of examination.

A third of the children had an episode of haematemesis or melaena. Interestingly, this did not necessarily occur early in the illness; more than half had had symptoms consistent with peptic ulcer

Table 1 Relation between reported age at onset of symptoms and delay in diagnosis

\begin{tabular}{lllll}
\hline Delay in diagnosis & \multicolumn{4}{l}{ Percentage of cases } \\
\cline { 2 - 5 } & $<1$ year & $1-2$ years & $3-5$ years & $>5$ years \\
\hline Age at onset: & & & & \\
(years) & 0 & 20 & 30 & 50 \\
$2-5(n=17)$ & 7 & 41 & 48 & 4 \\
$6-9(n=43)$ & 42 & 44 & 14 & 0 \\
$1(-13(n=50)$ & & & & \\
\hline
\end{tabular}

Table 2 Clinical features

\begin{tabular}{llll}
\hline & Total No(\%) & & Total No(\%) \\
\hline Abdominal pain & $99(90)$ & Vomiting & $43(39)$ \\
Periodicity & $78(71)$ & & \\
Nocturnal pain & $67(61)$ & Haemorrhage & $36(33)$ \\
Tenderness & $59(54)$ & & \\
Dyspepsia & $57(52)$ & Perforation & $0(0)$ \\
\hline
\end{tabular}

disease for at least a year before the episode of bleeding. As a presenting symptom upper gastrointestinal bleeding accounted for $36 \%$ of new cases in the 1960s. This figure had fallen to $15 \%$ by 1979 , almost certainly as a result of the policy of investigating larger numbers of children with abdominal pain. No child in this series suffered a perforation of their ulcer.

Two children have died; one as a result of an accident and one with Zollinger Ellison syndrome.

\section{Investigations}

Radiology. Of the 63 cases diagnosed by barium meal examination, two thirds had a demonstrable ulcer crater. The remaining third had severe distortion of the duodenal cap, together with the clinical features mentioned previously.

Endoscopy. From 1973, all cases were confirmed by endoscopic examination. From 1979, a deliberate change was made in the policy for selecting patients for investigation: in addition to those with a typical history suggesting peptic ulcer disease, and those with a history of gastrointestinal bleeding, children with recurrent abdominal pain who had had a history of nocturnal pain or a close family history of ulcer disease were also endoscoped. This change in policy resulted in a three-fold increase in the number of endoscopies performed annually; but the number of duodenal ulcers detected also increased by a factor of three (Table 3). Fifteen per cent had multiple ulcers; duodenitis was present in $50 \% ; 70 \%$ had obvious duodenal deformity and this was often severe and associated with scarring, suggesting long standing disease.

Acid secretion studies. Studies of acid production had been performed in 26 children. In seven of these betazole was used and in the remainder pentagastrin. Both of these agents produce comparable levels of acid secretion. ${ }^{7}$ Maximal acid output varied between 0.05 and $1.17 \mathrm{mmol} \mathrm{H} / \mathrm{kg} /$ hour (mean of $0 \cdot 52$ ). No control studies had been carried out. A study on 20 normal children aged between 2 and 12 years using pentagastrin reported a mean maximal

Table 3 Effect of changing selection criteria for endoscopy

\begin{tabular}{lcc}
\hline & $1973-78$ & $1979-85$ \\
\hline No of patients endoscoped & 54 & 189 \\
No of endoscopies/year* & 9 & 27 \\
No of duodenal ulcers detected & 9 & 38 \\
No of duodenal ulcers/year* & $1 \cdot 5$ & $5 \cdot 4$ \\
$\%$ of positive examinations & 20 & 20 \\
\hline *Average number & &
\end{tabular}


acid output of $0.372(\mathrm{SD}=0.089) \mathrm{mmol} \mathrm{H} \mathrm{H}^{+} / \mathrm{kg} /$ hour. ${ }^{8}$ Nine of the 26 investigated here had results greater than $2 \mathrm{SD}$ above this control mean.

\section{Treatment}

Until $\mathrm{H}_{2}$ receptor antagonists were introduced children were treated by various dietary manipulations, antacids, and, in a few cases, propantheline or carbenoxolone sodium. Thirty four children had been treated with either cimetidine $(25 \mathrm{mg} / \mathrm{kg} /$ day $)$, or latterly ranitidine (150 mg twice daily) for eight weeks. Thirty $(88 \%)$ had responded clinically to this initial course of treatment. As 70\% relapsed within six months of discontinuing treatment, however, those who seemed to have had peptic ulcer disease for a prolonged period, judged by the history or the finding of severe scarring and deformity on endoscopy, were given an additional six month course of nocturnal maintenance treatment. Nevertheless, longer periods of maintenance were needed by some children. One boy received a total of four years of treatment. No child suffered any side effects.

Fifteen patients are known to have had surgery (Table 4). One of these was the patient with Zollinger Ellison syndrome. He was diagnosed before cimetidine had been introduced. Despite surgery, he succumbed to his illness. Of the remaining 14, two were lost to follow up in our department soon after surgery and no information is available on their subsequent course.

Ten patients were followed up for between two and 15 years postoperatively. Two of these, having failed to benefit from an initial vagotomy and pyloroplasty, required a second and more radical acid reducing procedure (partial gastrectomy). Another had a recurrence of his disease at the age of 23 , seven years after surgery. Seven of these $10 \mathrm{had}$ remained asymptomatic when last seen.

\section{Follow up}

Only 15 of the 110 children were followed up for more than 10 years in the paediatric department, and half of these continued to complain of symptoms when last seen. The long term outcome of the patients in this series is the subject of a study currently in progress.

\section{Discussion}

This is the largest reported series of duodenal

Table 4 Details of subjects undergoing surgical procedures

\begin{tabular}{|c|c|c|c|c|c|c|c|}
\hline $\begin{array}{l}\text { Case } \\
\text { No }\end{array}$ & Sex & $\begin{array}{l}\text { Age } \\
\text { (years) at } \\
\text { diagnosis }\end{array}$ & $\begin{array}{l}\text { Age } \\
\text { (years) at } \\
\text { surgery }\end{array}$ & Indications & $\begin{array}{l}\text { Surgical } \\
\text { procedure(s) }\end{array}$ & $\begin{array}{l}\text { Postoperative } \\
\text { follow up } \\
\text { (years) }\end{array}$ & Outcome \\
\hline \multirow[t]{2}{*}{1} & \multirow[t]{2}{*}{$\mathbf{M}$} & \multirow[t]{2}{*}{14} & 17 & $\begin{array}{l}\text { Recurrent pain and } \\
\text { gastrointestinal blecding }\end{array}$ & 1 Vagotomy and pyloroplasty & \multirow[t]{3}{*}{2} & Symptoms continued \\
\hline & & & 19 & Recurrent pain & 2 Partial gastrectomy & & Unknown \\
\hline 2 & $\mathbf{M}$ & 12 & 14 & Recurrent pain & Vagotomy and pyloroplasty & & Unknown \\
\hline 3 & $\mathbf{M}$ & 14 & $\begin{array}{l}14 \\
17\end{array}$ & $\begin{array}{l}\text { Recurrent gastrointestinal blceding } \\
\text { Recurrent pain }\end{array}$ & $\begin{array}{l}1 \text { Vagotomy and pyloroplasty } \\
2 \text { Partial gastrectomy }\end{array}$ & $\begin{array}{l}3 \\
1\end{array}$ & $\begin{array}{l}\text { Symptoms continued } \\
\text { died (accident) at } 18 \text { yrs }\end{array}$ \\
\hline \multirow[t]{3}{*}{4} & \multirow[t]{3}{*}{$\mathbf{M}$} & \multirow[t]{3}{*}{8} & 8 & $\begin{array}{l}\text { Intractable pain and gastrointestinal } \\
\text { bleeding (Zollinger Ellison syndrome) }\end{array}$ & I Vagotomy and gastrectomy & $<1$ & No improvement \\
\hline & & & 8 & Vomiting. hypochloraemic alkalosis & $\begin{array}{l}2 \text { Relief of duodenal adhesion } \\
\text { and gastrectomy }\end{array}$ & 2 & Condition worsended \\
\hline & & & 10 & Surgery to search for tumour & 3 Unsuccessful exploration & & $\begin{array}{l}\text { Died shortly after surgery } \\
\text { (hepatic ZE-tumour } \\
\text { at pm) }\end{array}$ \\
\hline 5 & $\mathbf{M}$ & 10 & 17 & Recurrent pain & Vagotomy and pyloroplasty & 4 & No recurrence \\
\hline 6 & $\mathbf{F}$ & 10 & 25 & Recurrent pain & Vagotomy and pyloroplasty & & Unknown \\
\hline 7 & $\mathbf{M}$ & 10 & 14 & Recurrent pain & Partial gastrectomy & 15 & No recurrence \\
\hline 8 & $\mathbf{M}$ & 8 & 16 & Pyloric stenosis & Vagotomy and gastroenterostomy & 10 & $\begin{array}{l}\text { Symptoms returned } 7 \\
\text { years after surgery }\end{array}$ \\
\hline 9 & $\mathbf{M}$ & 10 & 10 & Intractable pain, melaena & Vagotomy and gastroenterostomy & 5 & No recurrence \\
\hline 10 & $\mathbf{M}$ & 11 & 16 & Recurrent pain, melaena & Vagotomy and gastroenterostomy & 7 & No recurrence \\
\hline 11 & $\mathbf{M}$ & 12 & 12 & Intractable pain, weight loss & Partial gastrectomy & 4 & No recurrence \\
\hline 12 & $\mathbf{M}$ & 9 & 12 & $\begin{array}{l}\text { Recurrent pain. and gastrointestinal } \\
\text { bleeding }\end{array}$ & Vagotomy and pyloroplasty & 8 & No recurrence \\
\hline 13 & $\mathbf{M}$ & 10 & 18 & Recurrent pain, duodenal stenosis & Vagotomy and pyloroplasty & 1 & No recurrence \\
\hline 14 & $\mathbf{M}$ & 12 & 14 & Recurrent pain & Partial gastrectomy & 1 & No recurrence \\
\hline 15 & $\mathbf{M}$ & 11 & 13 & Recurrent pain & Vagotomy and pyloroplasty & 2 & No recurrence \\
\hline
\end{tabular}


ulceration in childhood from a centre in Europe. ${ }^{5} 6$ 9-11 The published series from the North American continent and Europe suggest that large paediatric centres identify, on average, about two new cases annually, and rarely more than five. ${ }^{12-17}$

Between 1960 and 1972 one of the authors (RHJ) actively sought out cases from other hospital departments in the northern region, and this accounted in part for the large numbers seen in that period; no real comparison can therefore be made between the numbers at that time and subsequently. Neither is it possible to draw any conclusions about the local incidence of the disease.

Since 1973, however, the cases were all primary referrals. This was also the period in which paediatric endoscopy was introduced. The more liberal policy adopted in 1979 in selecting patients for investigation clearly had a strong impact on the numbers as the average annual detection rate rose from 1.5 to $5 \cdot 4$. The simultaneous decrease in the proportion presenting with overt gastrointestinal bleeding illustrates the fact that more of those being diagnosed in recent years have presented with abdominal pain rather than a complication of ulcer disease. This is of considerable importance as studies have shown that one third of patients found to have a duodenal ulcer subsequently suffer an episode of bleeding, and with treatment the risk of this occurrence can be reduced. ${ }^{18}$

Paediatric duodenal ulcers are not, as is often assumed, only found in adolescents. The onset may be in early childhood, as was seen in this series. The young child is less likely to give an accurate description of symptoms, and this together with a reluctance to consider the diagnosis in younger patients probably explains the occurrence of the longest delays in diagnosis in this group.

It is important to realise that many of these children do not have the typical clinical pain syndrome of non-radiating epigastric pain, which begins several hours after eating, and is relieved by food, antacids, or vomiting. Many presented with recurrent central abdominal pain unassociated with meal times. The high incidence of nocturnal pain in these children, however, is important: in Apley's series of recurrent abdominal pain only $7 \%$ of 118 children were woken at night by their pain. ${ }^{1}$

The high incidence of a family history of ulcer disease is striking. Clearly the percentage of cases with an affected first or second degree relative will depend on factors such as the number of relatives. A genetic study was carried out by RHJ, in which 44 affected children and their families were matched with 35 control families. In the families with duodenal ulcers $8 \cdot 2 \%$ of first and second relatives were affected, while in the control families only
$1.9 \%$ were so affected; this illustrates the real importance of genetic factors. ${ }^{19}$

The optimal management of this disorder remains to be established. Clearly the $\mathrm{H}_{2}$ receptor antagonists are effective in inducing a remission, as has also been shown in adults. The high relapse rate following withdrawal of treatment, however, also follows the pattern reported in older patients. ${ }^{18}$ The limited information available on the natural history of duodenal ulcer disease, beginning in childhood suggests that the diathesis may quite often persist into adult life. ${ }^{20}$ It may be that some patients will require protracted periods of treatment.

Considerable experience has now been gained in the use of the $\mathrm{H}_{2}$ receptor antagonists, especially cimetidine. Healing rates, symptomatic responses, and the effectiveness of maintenance treatment with cimetidine and ranitidine seem to be similar. ${ }^{21}$ Some rare specific side effects have been reported with cimetidine. It has been incriminated in cerebral and hepatic toxicity in children as well as in adults. ${ }^{22} 23$ In male children gynaecomastia may develop. ${ }^{24}$ Drowsiness and confusion have not been observed with ranitidine, and unlike cimetidine, it does not block androgen receptors, and gynaecomastia has not been reported. ${ }^{24}$ It is important to realise that serious side effects are rare with either drug. Potential hazards must be balanced against the definite morbidity and mortality risks associated with surgery.

In conclusion, we suspect that awareness of the commonly atypical presentation of this disorder, especially in young children might result in earlier diagnosis. We wish to emphasise the importance of investigating those children with recurrent abdominal pain associated with nocturnal pain, or those who have a family history of peptic ulcer disease. Early recognition and treatment may reduce both morbidity and the incidence of complications.

Dr M S Murphy is an Action Research Training Fellow.

\section{References}

' Apley J. The child with abdominal pain. Oxford: Blackwell Scientific Publications, 1975.

2 Ament ME, Christic DL. Upper gastrointestinal fiberoptic endoscopy in paediatric patients. Gastroenterology 1977; 72:1244-8.

${ }^{3}$ Miller V, Doig CM. Upper gastrointestinal tract endoscopy. Arch Dis Child 1984;59:1100-2.

${ }^{4}$ Sultz HA, Schlesinger ER, Feldman JG, Mosher WE. The epidemiology of peptic ulcer in childhood. Am J Pub Health 1970;60:492-8.

5 Robb JDA, Thomas PS, Orszulok J, Odling-Smee GW Duodenal ulcer in children. Arch Dis Child 1972:47:688-96.

- Habbick BF, Melrose AG, Grant JC. Duodenal ulcer in childhood; a study of predisposing factors. Arch Dis Child 1968;43:23-8. 
${ }^{7}$ Isenberg JI. Peptic ulcer disease. In: Sleisenger MH, Fordtran JS, eds. Gastrointestinal disease. Pathophysiology diagnosis management. London: WB Saunders Company, 1978;717.

${ }^{8}$ Fieber M, Meschede R, Tolckmitt W. Aciditat und Peptische Aktivitat des Magensafts bei gesunden und Mucoviscidosis kranken Kindern. Z Kinderkeilkd 1975;120:199-209.

9 Goldberg HM. Duodenal ulcers in children. $\mathrm{Br}$ Med $\mathrm{J}$ $1957 ; \mathbf{i}: 1500-2$.

10 Milliken JC. Duodenal ulceration in children. Gut 1965;6: 25-28.

11 Kumar D, Spitz L. Peptic ulceration in children. Surg Gynecol Obstet 1984;159:63-6.

${ }^{12}$ Fallstrom SP, Reinand T. Peptic ulcer in children. Acta Paediatr Scand 1961;50:431-6.

13 Singilton EB, Faykus MH. Incidence of peptic ulcer as determined by radiologic examination in the pediatric age group. J Pediatr 1964;6:858-62.

14 Seagram CGF, Stephens CA, Cumming WA. Peptic ulceration at the Hospital for Sick Children, Toronto, during the 20-year period 1949-1969. J Pediatr Surg 1973;8:407-13.

15 Deckelbaum RJ, Roy CC, Lussier-Lazaroff J, Morin CL. Peptic ulcer disease: a clinical study in 73 children. Can Med Assoc J 1974;111:225-8.

16 Tolia V, Dubois RS. Peptic ulcer disease in children and adolescents. Gastroenterology 1983;2:665-9.
${ }^{17}$ Curci MR, Little K, Sieber WK, Kiesewetter WB. Peptic ulcer disease in childhood re-examined. J Pediatr Surg 1984;11: 329-35.

${ }^{18}$ Boyd EJS, Wilson JA, Wormsley KG. Review of ulcer treatment: role of ranitidine. J Clin Gastroenterol 1983;5: 133-41.

19 Jackson RH. Genetic studies in peptic ulcer disease in childhood. Acta Paediatr Scand 1972;61:493-4.

20) Puri P, Boyd E, Blake N, Guiney EJ. Duodenal ulcer in childhood: a continuing disease in adult life. J Pediatr Surg 1978;13:525-6.

21 Brogden RN, Carmine AA, Heel RC, et al. Ranitidine: a revicw: of its pharmacology and theraputic use in peptic ulcer disease and other allied diseases. Drugs 1982;24:267-303.

22 Bale JF, Roberts C, Brook L. Cimetidine induced cerebral toxicity in children. Lancet 1979;i:725-6.

${ }^{23}$ Lilly JR, Hitch DC, Javitt NB. Cimetidine cholestatic jaundice in children. J Surg Res 1978;24:348-7.

${ }^{24}$ Ranitidine v. cimetidine in peptic ulcer. Drug Ther Bull 1982;20:57-9.

Correspondence to Dr EJ Eastham, Department of Child Health, Royal Victoria Infirmary, Newcastle upon Tyne, NE1 4LP.

Received 23 January 1987 